\title{
Comparative Analysis of Relative Permeability Models with Reference to Extreme Saturation Limit and Its Influence on Reservoir Performance Prediction (Analisis Perbandingan Model Ketelusan Bandingan dengan Merujuk kepada Had Tepu Melampau dan Pengaruhnya terhadap Jangkaan Prestasi Takungan)
}

\author{
MUHAMMAD KHURRAM ZAHOOR*
}

\begin{abstract}
A number of relative permeability models were present in the literature, which were used to generate relative permeability data for the fluids, present in the porous medium. Some models were more significant to reservoir geology and displacement system (imbibitions and drainage system), while developing the correlations. Similarly, the same is kept in mind while performing reservoir studies. Therefore, in this study different models based on displacement system and formation geology have been compared, while including the effect of fluid saturation distribution/end point saturation in a reservoir. The generated relative permeability data by using these models have been further used to predict the reservoir performance for gas and water-displacement systems. The results based on this study showed that at lower saturations of displacing fluid (gas and/or water), the generated reservoir performance curves based on relative permeability data generated by using Corey and Wylie and Gardner models, gives higher degree of deviation on comparative basis. The behavior of these error or deviation curves for displacing phase is opposite in case of gas and water-oil displacement systems. While in case of displaced phase (oil), generally analogous behavior can be observed for both systems in terms of deviation/ error profiles trends. These reservoir performance curve(s) are of utmost significance in developing reservoir in an appropriate manner and a slight variation in relative permeability data can have a significant impact at macroscopic level.
\end{abstract}

Keywords: Performance prediction; relative permeability data; saturation variation effect

ABSTRAK

Beberapa model ketelusan bandingan sedia ada yang digunakan untuk menjana data ketelusan bandingan untuk cecair, hadir dalam medium berliang. Sesetengah model berkepentingan kepada takungan geologi dan anjakan sistem (pemedapan dan sistem saliran) dalam membangunkan korelasi. Begitu juga, perkara yang sama perlu difikirkan semasa menjalankan kajian takungan. Oleh yang demikian, dalam kajian ini model yang berbeza berdasarkan kepada anjakan sistem dan pembentukan geologi telah dibandingkan dengan mengambil kira kesan pengagihan cecair tepu/titik akhir tepu di dalam takungan. Data ketertelapan relatif yang dijana menggunakan model-model ini seterusnya digunakan untuk meramalkan prestasi takungan untuk sistem gas dan air-anjakan. Hasil kajian ini menunjukkan bahawa pada penepuan anjakan bendalir (gas dan/atau air) yang lebih rendah, lengkung prestasi takungan yang dijana berdasarkan data ketelusan bandingan menggunakan model Corey dan Wylie \& Gardner, memberi darjah sisihan piawai lebih tinggi secara perbandingan. Tingkah laku kesilapan ini atau lengkung sisihan bagi fasa anjakan adalah bertentangan dalam kes sistem gas dan anjakan air-minyak. Manakala dalam kes fasa anjakan (minyak), secara umumnya tingkah laku analog boleh diperhatikan bagi kedua-dua sistem daripada segi trend sisihan/ profil ralat. Prestasi lengkungan takungan ini adalah amat penting dalam membangunkan takungan dengan cara yang betul dan sedikit perbezaan dalam data ketertelapan relatif boleh mempunyai kesan yang ketara pada peringkat makroskopik.

Kata kunci: Data kadar resapan yang relatif; jangkaan prestasi; kesan perubahan tepu

\section{INTRODUCTION}

One of the utmost parameter, namely; 'permeability', gives an insight into fluid flow dynamics within the porous medium. Permeability can be described by effective and relative permeability terms, if more than one fluid is present within a reservoir (Ahmed 2000; Craig 1971). To estimate fluid flow behavior, different models/ correlations have been proposed from time to time for gas- and water displacement systems. These models vary in sensitivity with respect to variations in minimum saturation and degree of sorting (Brooks \& Corey 1966; Corey 1954). Different studies (Ahmed 2000; Honarpour et al. 1986; Li 2010; Naar \& Henderson 1961) are available in the literature to describe relative permeability curve behavior by using these correlations and recently an in-depth sensitivity analysis of Brooks and Corey model (Brooks \& Corey 1966) and Pirson correlation (Pirson 1958) was studied and analyzed by Zahoor in 2011 (Zahoor 2011), using the in-house developed software, namely; Kr Estimator. In this 
paper, the study is further extended and broadened by including more relative permeability models, which are used for generating relative permeability data, based on the information, such as type of fluids present in the reservoir, formation type, undergoing displacement processes and saturation variations. Furthermore, to show the significance of selecting such models and saturation variations at macroscopic scale, reservoir performance calculations have been accomplished and correspondingly the percentage deviation in reservoir performance calculations has been estimated.

\section{Fluid DisPlacement Systems in A PoRous Medium}

Fluid flow through porous medium or fluid dynamics in a reservoir involves a lot of complexity (Ahmed 2000; Gatlin 1960). The number of parameters can hinder the fluid flow and a displacement of one fluid by another in a reservoir. Such parameters involve wettability as of prime importance (Ahmed 2000; Zahoor \& Derahman 2013; Zahoor et al. 2011). Wettability, in turn also affects the relative permeability of displacing and displaced fluids, as shown in Figure 1.

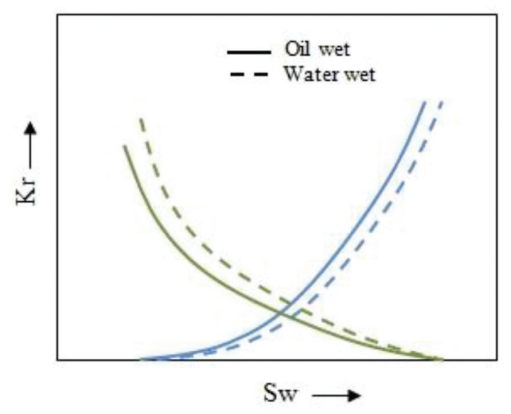

FIGURE 1. Effect of wetability on relative permeability permeability $(\mathrm{Kr})$ versus water saturation $(\mathrm{Sw})$ curves (Zahoor et al. 2011)

Figure 1 shows that the wetting phase has lesser relative permeability as compared to the non-wetting phase, because the wetting phase occupies the smaller pores while the non-wetting phase occupies the larger pores. The analogous situation exists in case of using different relative permeability models. If in one model, let say the permeability of oil (displaced phase) is higher, then in the other model the permeability of water or gas (displacing phase) will be comparatively higher and the oil relative permeability curve will shift downward (representing lower relative permeability values).

However, to keep it simple, in the later discussion regarding flow dynamics and relative permeability models, water will be considered as wetting phase. Displacement of fluid within a porous medium can be described as imbibition and drainage process. In imbibition process, wetting phase displaces the non-wetting phase or in other words saturation of wetting phase increases while the saturation of non-wetting phase decreases. For example, water displacing oil (non-wetting phase). In drainage process, wetting phase is displaced by a non-wetting phase. One of the typical examples of such systems is gas displacing oil, as in such systems oil is generally considered as wetting phase. This displacement behavior is reflected by relative permeability curves of displacing and displaced fluids. The fluid with higher permeability will flow faster in a reservoir as compared to the other fluid(s) present within a reservoir. This is shown in Figure 2.

Figure 2, shows the effect of change in effective permeability of the displacing fluid (gas or water). Mathematically effective permeability is calculated from relative permeability by using the following equation (Gatlin 1960):

$$
k_{e}=k \times k_{r}
$$

where ' $\mathrm{k}$ ' represents absolute permeability while, ' $\mathrm{k}$ ' and ' $\mathrm{k}_{\mathrm{r}}$ ' represents effective and relative permeability, respectively. Let Figure 2(a), shows the front location at time ' $t$ ' with the displacing fluid having an effective permeability ' $\mathrm{k}_{\mathrm{e} 1}$ '. But, if the effective permeability of the displacing fluid is higher than ' $\mathrm{k}_{\mathrm{el}}$ ', the displacement process becomes faster and correspondingly the displacement front will travel more in distance (Figure 2(b)) as compared to the first case. Therefore, to analyze the flow of fluid within the porous medium, good knowledge of relative permeability models and accurate data sets are required for proper reservoir surveillance studies.

\section{RELATIVE PERMEABILITY MODELS}

In this study, the relative permeability models taken into consideration for thorough sensitivity analysis of the generated data are described in Table 1, for compact view. Corey model (Corey 1954) can be applied in gas-oil drainage processes for any kind of porous medium, while on the other hand Wyllie and Gardner (1958) govern a group of correlations based on fluid system and formation nomenclature.

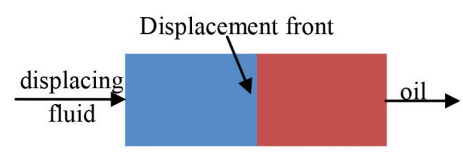

(a)

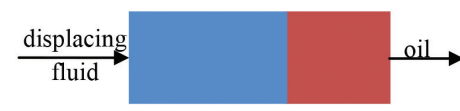

(b) 
TABLE 1. Brief description of relative permeability models

\begin{tabular}{|c|c|c|c|c|c|c|}
\hline \multirow{2}{*}{$\begin{array}{l}\text { Relative } \\
\text { permeability } \\
\text { models }\end{array}$} & \multicolumn{3}{|c|}{ Correlations } & \multirow{2}{*}{$\begin{array}{c}\text { Fluid } \\
\text { dependency/ } \\
\text { displacement } \\
\text { system } \\
\end{array}$} & \multirow{2}{*}{$\begin{array}{l}\text { Formation } \\
\text { type }\end{array}$} & \multirow{2}{*}{$\begin{array}{l}\text { Displacement } \\
\text { process }\end{array}$} \\
\hline & $\mathrm{k}_{\mathrm{ro}}$ & $\mathrm{k}_{\mathrm{rw}}$ & $\mathrm{k}_{\mathrm{rg}}$ & & & \\
\hline \multirow[t]{2}{*}{ Corey } & $\left(\mathrm{S}_{\mathrm{oe}}\right)^{4}$ & & $\left(1-S_{\mathrm{oe}}\right)^{2}\left(1-S_{\mathrm{oe}}^{2}\right)$ & Gas-oil & -- & Drainage \\
\hline & $\begin{array}{c}\left(S_{0}^{*}\right)^{3} \\
\left(1-S_{w}^{*}\right)^{3}\end{array}$ & $\left(S_{w}^{*}\right)^{3}$ & $\left(1-S_{0}^{*}\right)^{3}$ & $\begin{array}{l}\text { Gas-oil and } \\
\text { water-oil }\end{array}$ & $\begin{array}{l}\text { Unconsolidated } \\
\text { well sorted sand }\end{array}$ & \\
\hline \multirow[t]{2}{*}{$\begin{array}{l}\text { Wyllie and } \\
\text { Gardner }\end{array}$} & $\begin{array}{c}\left(S_{\mathrm{o}}^{*}\right)^{3.5} \\
\left(1-S_{\mathrm{w}}^{*}\right)^{2}\left(1-\left(\mathrm{S}_{\mathrm{w}}^{*}\right)^{1.5}\right)\end{array}$ & $\left(S_{\mathrm{w}}^{*}\right)^{3.5}$ & $\left(1-S_{\mathrm{o}}^{*}\right)^{2}\left(1-\left(\mathrm{S}_{\mathrm{o}}^{*}\right)^{1.5}\right)$ & & $\begin{array}{l}\text { Unconsolidated } \\
\text { poorly sorted } \\
\text { sand }\end{array}$ & Drainage \\
\hline & $\begin{array}{c}\left(S_{\mathrm{o}}^{*}\right)^{4} \\
\left(1-S_{w}^{*}\right)^{2}\left(1-\left(S_{w}^{*}\right)^{2}\right)\end{array}$ & $\left(S_{w}^{*}\right)^{4}$ & $\left(1-S_{\circ}^{*}\right)^{2}\left(1-\left(S_{\circ}^{*}\right)^{2}\right)$ & & $\begin{array}{l}\text { Cemented } \\
\text { sandstone, } \\
\text { oolitic } \\
\text { limestone, rocks } \\
\text { with vugular } \\
\text { porosity }\end{array}$ & \\
\hline
\end{tabular}

where ' $\mathrm{k}_{\mathrm{rg}}$ ', ' $\mathrm{k}_{\mathrm{ro}}$ ' and ' $\mathrm{k}_{\mathrm{rw}}$ ' represent relative permeability to gas, oil and water respectively. $\mathrm{S}^{*}$ (or $\mathrm{S}_{\mathrm{e}}$ ) represents effective or normalized saturation and the subscripts ' $\mathrm{o}$ ' and ' $w$ ' represents oil and water, respectively.

\section{COMPARATIVE ANALYSIS OF RELATIVE PERMEABILITY MODELS}

The developed state-of-the-art $\mathrm{K}_{\mathrm{r}}$ Estimator has been effectively used for relative permeability data generation and brief comparative analysis at micro-scale (Zahoor 2011). In this paper, the study is further extended and a number of relative permeability models which are based on formation type and displacement systems, i.e. for gasoil and water-oil system have been included. To generate relative permeability curves, displacing phase minimum saturation (gas and water) is varied from ' 0 ' to ' 0.3 ' with the incremental interval of ' 0.1 ' (or in other words displaced phase maximum saturation is varied from ' 1.0 ' to ' 0.7 ') and the data has been generated for the models which are described in Table 1.

The obtained results is shown in Figures 3 to 6 . Analysis of the obtained results can be discussed while categorizing them into two major displacement systems, i.e. gas-oil and water-oil system.

In case of gas-oil displacement system (Figures 3 and 4), it has been observed that Corey model generates relative permeability data similar to the correlations developed by Wyllie and Gardner for cemented formations. Furthermore, the obtained relative permeability data shows that the curves generated for unconsolidated well sorted formations have upward trend as compared to curves generated for unconsolidated poorly sorted formations in cases when gas is displacing oil, while the vice versa situation exists in case of water displacing oil. This is due to the difference in displacement behavior of gas and water. Gas tends to

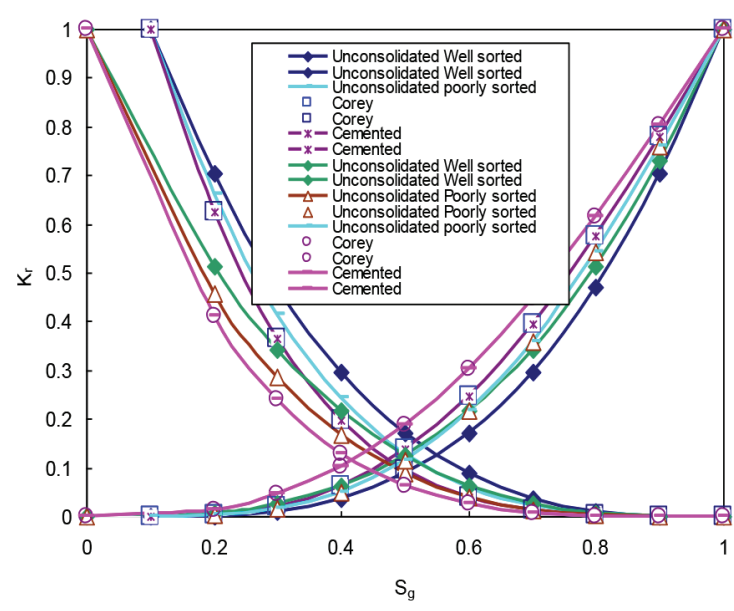

FIGURE 3. Effect of maximum displaced fluid saturation (1.0 to $0.9)$ on relative permeability data generation

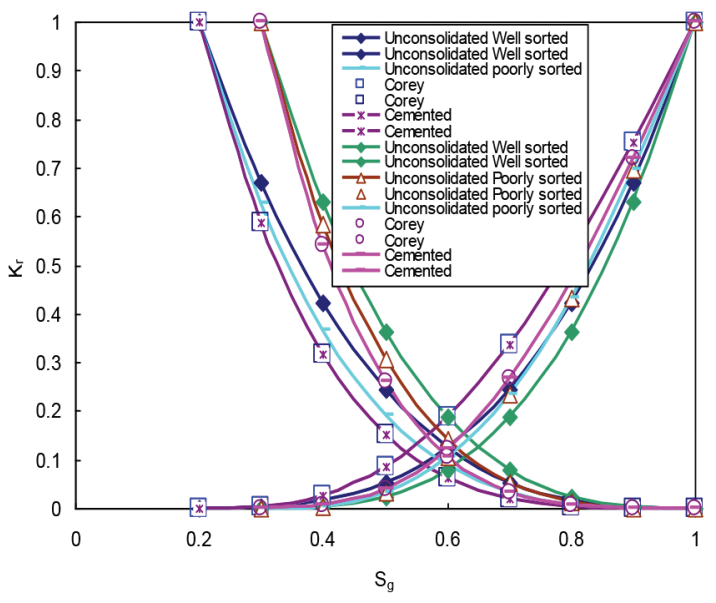

FIGURE 4. Curves representing effect of maximum displaced fluid saturation of 0.8 and 0.7 on relative permeability 


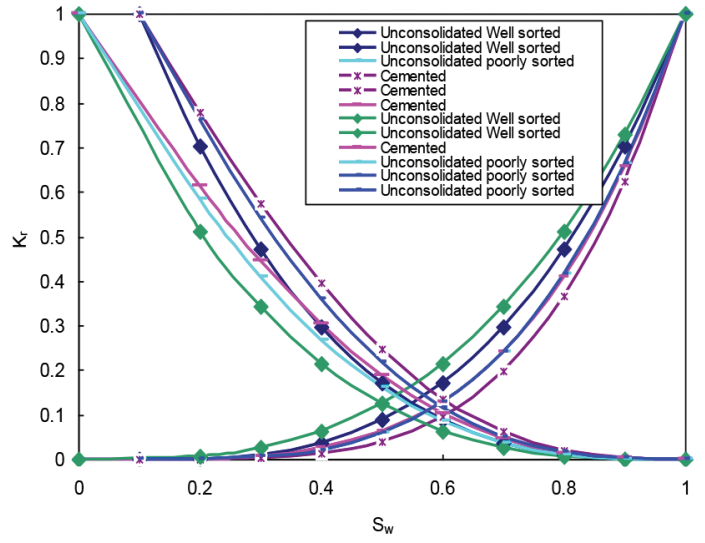

FIGURE 5. Influence of change in minimum water saturation ( 0 to 0.1 ) on relative permeability data

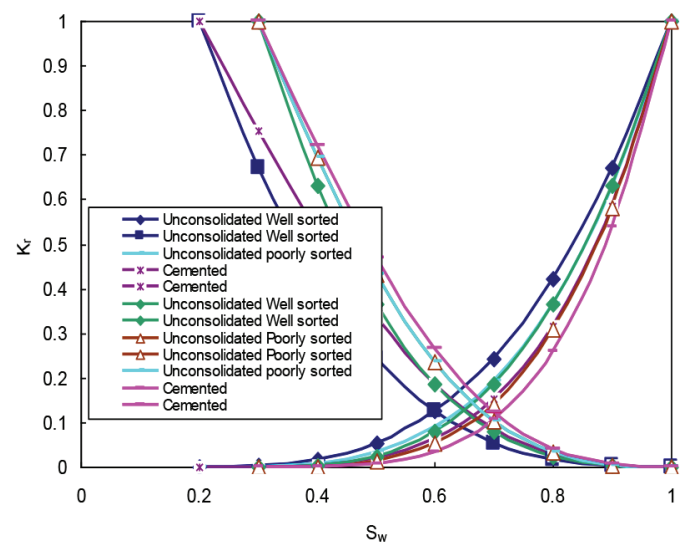

FIGURE 6. Effect of minimum water saturation of 0.2 and 0.3 on relative permeability curves

follow (being lighter) the lesser restrictive paths while water, being making use of capillary phenomenon, also prefer to imbibe through narrow paths.

Further detailed analysis of the obtained results as a result of this study has been presented in Table 2, where $S_{\text {min }}$ refers to minimum saturation of the displacing fluid. In this Table, the ranking of the correlations under consideration have also been established on the basis of highest to lowest relative permeability values generated for displaced fluid. where $\mathrm{S}_{\text {min }}$ represents minimum saturation values of displacing fluid. Generated data from relative permeability models while incorporating saturation variations is further used to analyze and predict the reservoir performance, based on which, tubing sizing, well spacing and surface facilities are designed (Economides et al. 1994; Feroney et al. 2009; Ridha 2003). These facilities also require corrosion protection, which also add to the total expenditure of field development (Ahmed et al. 2011). Therefore, good accuracy and precision in relative permeability data is required to avoid the under- and overestimation of reservoir behavior. Since nature has lots of variations and though in the case of reservoirs, a good representative data is highly required to develop the assets in an optimized manner. Mostly, the models are used to generate relative permeability data for reservoirs, as being extensive areal extent of reservoirs, E\&P companies have to predict the data, especially for the areas where pressure transient have not been moved during well testing. This situation has further become very challenging nowadays, when due to environmental issues, the testing has been reduced, resulting in even lesser degree of data available to the companies, exposing them in turn, to higher degree of uncertainty and making them more dependent on relative permeability models.

In the next section, reservoir fluid production (oil and water in case of oil-water system and oil and gas in case of gas-oil system) as well as gas- and water-cut have been calculated by using the above generated relative permeability data.

\section{EFFECT OF GENERATED RELATIVE PERMEABILITY DATA ON RESERVOIR PERFORMANCE PREDICTION}

Consider a reservoir having a length of $100 \mathrm{ft}$ and an area of $1500 \mathrm{ft}^{2}$. Further details of reservoir and fluid properties are given in Table 3 .

In order to analyze the effect of previously discussed relative permeability models on reservoir performance and prediction; oil, water and gas production rates have been calculated along with gas and water-cut. The production rates have been calculated by using the following set of equations (Ahmed 2000; Gatlin 1960):

TABLE 2. Ranking of correlations based on generated $\mathrm{K}_{\mathrm{r}}$ data with reference to fluid system and saturation variation

\begin{tabular}{lll}
\hline & $\mathrm{S}_{\min }$ Values & Correlation Type \\
\hline Gas-oil displacement system & $0.0,0.1,0.2,0.3$ & $\left.\begin{array}{l}\text { Unconsolidated well sorted } \\
\text { Unconsolidated poorly sorted } \\
\text { Corey model } \\
\text { Cemented }\end{array}\right\}$ Generates similar $\mathrm{K}_{\mathrm{r}}$ \\
& & $\begin{array}{l}\text { Unconsolidated poorly sorted } \\
\text { Cemented }\end{array}$ \\
Water-oil displacement system & $0.0,0.1,0.2,0.3$ & Unconsolidated well sorted \\
& & \\
\hline
\end{tabular}


TABLE 3. Reservoir and fluid properties

\begin{tabular}{lc}
\hline Reservoir & Fluid properties \\
\hline Absolute permeability, $\mathrm{K}_{\mathrm{abs}}$ & $100 \mathrm{md}$ \\
Average reservoir pressure, $\mathrm{P}_{\mathrm{R}}$ & $2500 \mathrm{psia}$ \\
Wellbore flowing pressure, $\mathrm{P}_{\mathrm{wf}}$ & $500 \mathrm{psia}$ \\
Reservoir temperature, $\mathrm{T}$ & $620^{\circ} \mathrm{R}$ \\
Oil formation volume factor, $\mathrm{B}_{\mathrm{o}}$ & $1.134 \mathrm{bbl} / \mathrm{stb}$ \\
Water formation volume factor, $\mathrm{B}_{\mathrm{w}}$ & $1.00 \mathrm{bbl} / \mathrm{stb}$ \\
Oil viscosity, $m_{\mathrm{o}}$ & $1.20 \mathrm{cp}$ \\
Gas Viscosity, $m_{\mathrm{g}}$ & $0.028 \mathrm{cp}$ \\
Water viscosity, $m_{\mathrm{w}}$ & $1.0 \mathrm{cp}$ \\
\hline
\end{tabular}

$$
\begin{aligned}
& q_{g}=111.98 \times 10^{-3} \frac{k_{g} A\left(P_{R}^{2}-P_{w f}^{2}\right)}{Z \mu_{g} L T}, \\
& q_{o}=1.127 \times 10^{-3} \frac{k_{o} A\left(P_{R}-P_{w f}\right)}{\mu_{o} B_{o} L}, \\
& q_{w}=1.127 \times 10^{-3} \frac{k_{w} A\left(P_{R}-P_{w f}\right)}{\mu_{w} B_{w} L},
\end{aligned}
$$

where q represents flow rate and the subscripts ' $\mathrm{o}$ ', ' $\mathrm{w}$ ' and ' $\mathrm{g}$ ' refers to oil, water and gas. 'A' is the area and ' $\mathrm{Z}$ ' stands for gas deviation factor. The water and gas-cut $\left(\mathrm{f}_{\mathrm{w}}\right.$ and $\mathrm{f}_{\mathrm{g}}$ ) have been calculated by using the following equations (Ahmed 2000):

$$
f_{w}=\frac{1}{1+\frac{k_{r o} \mu_{w}}{\mu_{o} k_{r w}}},
$$

and

$$
f_{g}=\frac{1}{1+\frac{k_{r o} \mu_{g}}{\mu_{o} k_{r g}}} .
$$

In this study, to highlight and analyze the effect and significance of relative permeability models selection for reservoir performance calculations, the data was used in (2) to (6), corresponding to various saturation values from Figures 4 (gas-oil system) and 6 (water-oil system). The trend of the obtained results in case of gas-oil system for their production rates, gas-cut are shown in Figure 7 with reference to saturation, respectively. The details of the generated data with reference to smaller step change in saturation and comparative analysis of Corey model is given in Tables 4 and 5, respectively. Figure 7 shows that the behavior of gas and oil production profiles is similar to as that of their relative permeability data, i.e. as the relative permeability of any phase increases or decreases, the production rate also follows the same trend of variation. Gas and oil production curves show a quite uniform behavior with the variation in relative permeability. Furthermore, the deviation of calculated oil and gas flow rates based on above discussed model(s) has been calculated using (7) and the obtained trend is shown in Figure 8.

$$
\% \text { Error }=\frac{Q_{f, \text { well sored }}-Q_{f}}{Q_{f, \text { well sorted }}} \times 100,
$$

where ' $Q$ ' represents the flow rate and the subscript ' $f$ ' refers to fluid (gas, oil and water) for which error or deviation has to be calculated. In order to determine the percentage deviation/error, for calculated flow rates, gasand water-cuts; production data calculated by using the relative permeability data obtained by using Wyllie and Gardner correlation for unconsolidated well sorted sand has been used as base/ reference case.

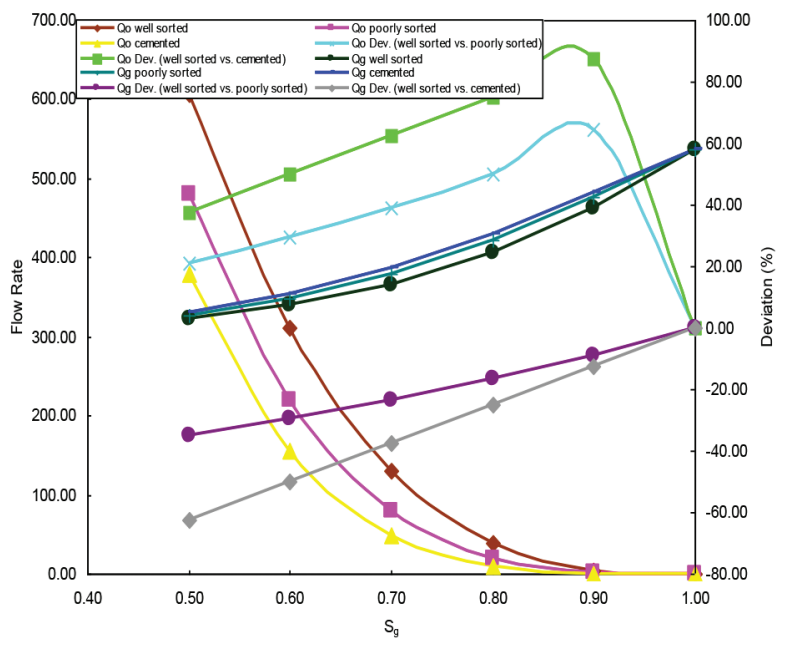

FIGURE 7. Production rate of oil (Stb/day), gas (MScf/day), percentage error in their estimation with reference to gas saturation $\left(\mathrm{S}_{\mathrm{g}}\right)$

Figure 8 shows that at lower oil saturation $\left(1-\mathrm{S}_{\mathrm{g}}\right)$, percentage deviation or error in oil production is higher with reference to base case, but it decreases as the oil saturation increases. This is due to the fact that the generated $\mathrm{K}_{\mathrm{r}}$ data by using various models represents greater degree of variation on comparative basis, resulting into significant deviation in oil production calculations. While in case of gas flow rate and its deviation with the reference case, it represents a uniform trend, representing the consistency of relative permeability data generated using the above discussed models.

Further gas-cut calculated using previous discussed models represents almost the same trend at higher gas saturations and the difference becomes evident at comparatively lower saturations (Figure 8). As gas has high mobility, it is less influenced by degree of sorting and degree of cementation, thus the effect of narrow flow paths (due to poor sorting) on gas-cut profiles becomes evident at lower gas saturations.

Reservoir production profiles and percentage (\%) deviation curves for water-oil displacement system are shown in Figures 9 and 10 and the detailed results with reference to saturation change are given in Table 6 . The trend of profiles for displacing phase (water) is quite similar to that of previous case (gas), such that uniform 


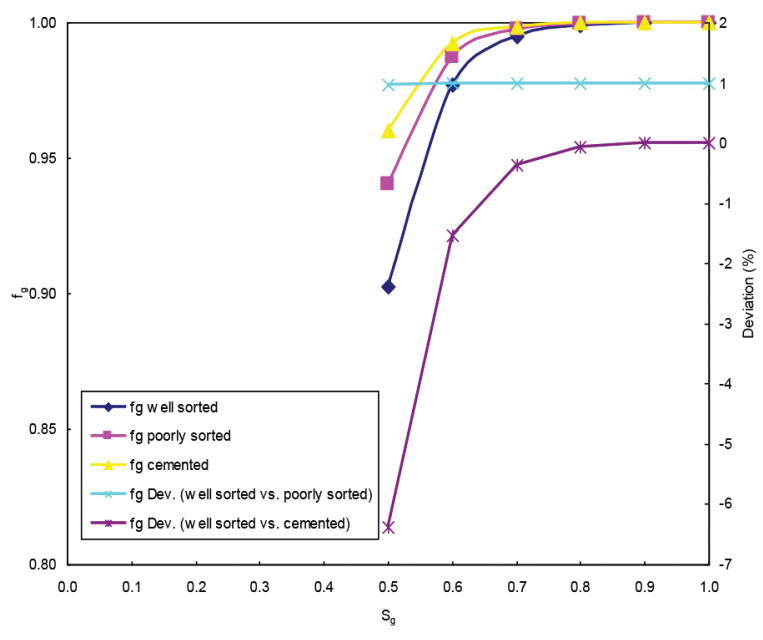

FIGURE 8. Calculated gas-cut and percentage deviation/error in gas-oil displacement system

trend in increase in percentage error or deviation can be observed. Though the trends of variation is opposite, i.e. in gas-oil system the calculated displacing phase flow rate have higher values as compared to the base case while its vice versa in case of water-oil system. Similarly the opposite trends in deviation of oil phase calculation in both systems can be observed, i.e. in earlier case it is lesser with reference to base case while it is higher in later case.

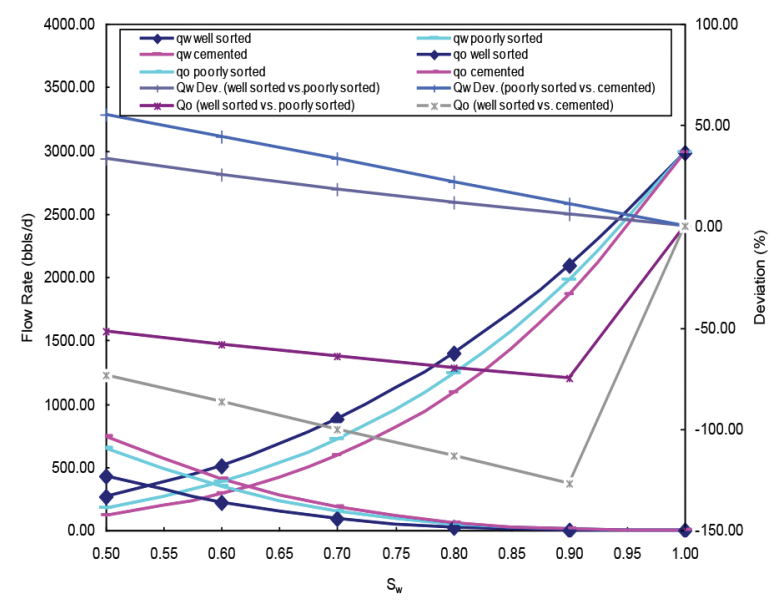

FIGURE 9. Production profiles of displacing and displaced fluids along with percentage error with reference to water saturation $\left(\mathrm{S}_{\mathrm{w}}\right)$ in case of oil-water system

TABLE 4. Results obtained for saturation step change in different types of formations

\begin{tabular}{|c|c|c|c|c|c|c|c|c|c|c|c|c|c|c|c|c|c|c|c|c|c|}
\hline & \multicolumn{5}{|c|}{ Unconsolidated Well Sorted } & \multicolumn{5}{|c|}{ Unconsolidated Poorly Sorted } & \multicolumn{5}{|c|}{ Cemented } & \multicolumn{6}{|c|}{ Deviation $(\%)$} \\
\hline & & & & & & & & & & & & & & & & & Gorted vs. & & Wells & vied vs. C & mented \\
\hline$S_{g}$ & $K_{0}$ & $\mathrm{~K}_{\mathrm{gg}}$ & $Q_{0}$ & $Q_{g}$ & $f_{g}$ & $K_{10}$ & $K_{g}$ & $Q_{0}$ & $Q_{g}$ & $f_{g}$ & $K_{10}$ & $K_{\text {g }}$ & $Q_{0}$ & $Q_{g}$ & $f_{g}$ & $Q_{0}$ & $Q_{g}$ & $f_{g}$ & $Q_{0}$ & $Q_{g}$ & $f_{g}$ \\
\hline & & & & & & & & & & & & & & & & & & & & & \\
\hline 0.475 & 0.2826 & 0.0406 & \begin{tabular}{|l|l|}
702.20 \\
\end{tabular} & 236 & 0.86 & 0.2290 & 0.0553 & \begin{tabular}{|l|l|}
568.84 \\
\end{tabular} & 3.21 & 0.91 & 0.1855 & 0.0673 & 4460.82 & 3.91 & 0.94 & 18.99 & -36.26 & 0.94 & 34.38 & -65.63 & -9.21 \\
\hline 0.45 & 0.3250 & 0.0305 & 807.36 & 1.77 & 0.80 & 0.2694 & 0.0420 & 669.43 & 2.44 & 0.87 & 0.2234 & 0.0515 & 555.06 & 2.99 & 0.91 & 17.08 & -37.59 & 0.91 & 31.25 & .68 .75 & \begin{tabular}{|l|l|}
-13.37 \\
\end{tabular} \\
\hline 0.425 & 0.3713 & 0.0222 & 922.54 & 1.29 & 0.72 & 0.3148 & 0.0309 & 782.12 & 1.79 & 0.81 & 0.2669 & 0.0382 & 663.07 & 2.22 & 0.86 & 15.22 & -38.90 & 0.86 & 28.13 & .71 .88 & -19.48 \\
\hline 0.4 & 0.4219 & 0.0156 & 1048.18 & 0.91 & 0.61 & 0.3654 & 0.0219 & 907.75 & 1.27 & 0.72 & 0.3164 & 0.0273 & 786.13 & 1.59 & 0.79 & 13.40 & -40.19 & 0.79 & 25.00 & .75 .00 & -28.35 \\
\hline 0.375 & 0.4768 & 0.0105 & 1184.73 & 0.61 & 0.48 & 0.4215 & 0.0148 & 1047.17 & 0.86 & 0.60 & 0.3725 & 0.0186 & 925.57 & 1.08 & 0.68 & 11.61 & -41.47 & 0.68 & 21.88 & .78 .13 & -40.70 \\
\hline 0.35 & 0.5364 & 0.0066 & 1332.66 & 0.38 & 0.34 & 0.4835 & 0.0094 & 1201.25 & 0.55 & 0.45 & 0.4358 & 0.0119 & 1082.79 & 0.69 & 0.54 & 9.86 & -42.73 & 0.54 & 18.75 & -81.25 & \begin{tabular}{|c|}
.56 .59 \\
\end{tabular} \\
\hline 0.325 & 0.6007 & 0.0038 & 1492.42 & 0.22 & 0.21 & 0.5518 & 0.0055 & 1370.88 & 0.32 & 0.30 & 0.5068 & 0.0070 & 1259.23 & 0.41 & 0.37 & 8.14 & -43.98 & 0.37 & 15.63 & -84.38 & -74.32 \\
\hline 0.3 & 0.6699 & 0.0020 & \begin{tabular}{|l}
1664.47 \\
\end{tabular} & 0.11 & 0.11 & 0.6267 & 0.0028 & 1556.97 & 0.16 & 0.16 & 0.5862 & 0.0037 & 1456.41 & 0.21 & 0.21 & 6.46 & -45.21 & 0.21 & 12.50 & .87 .50 & .90 .15 \\
\hline 0.275 & 0.7443 & 0.0008 & \begin{tabular}{|l}
1849.25 \\
\end{tabular} & 0.05 & 0.05 & 0.7085 & 0.0012 & \begin{tabular}{|l}
1760.43 \\
\end{tabular} & 0.07 & 0.07 & 0.6745 & 0.0016 & \begin{tabular}{|l}
1675.88 \\
\end{tabular} & 0.09 & 0.09 & 4.80 & -46.43 & 0.09 & 9.38 & -90.63 & \begin{tabular}{|c|}
-100.33 \\
\end{tabular} \\
\hline 0.25 & 0.8240 & 0.0002 & 2047.22 & 0.01 & 0.01 & 0.7978 & 0.0004 & 1982.21 & 0.02 & 0.02 & 0.7725 & 0.0005 & 1919.27 & 0.03 & 0.03 & 3.18 & -47.63 & 0.03 & 6.25 & -93.75 & \begin{tabular}{|c|} 
\\
\end{tabular} \\
\hline 0.225 & 0.9091 & 0.0000 & 2258.84 & 0.00 & 0.00 & 0.8948 & 0.0000 & 2223.27 & 0.00 & 0.00 & 0.8807 & 0.0001 & 2188.25 & 0.00 & 0.00 & 1.57 & -48.82 & 0.00 & 3.13 & .96 .88 & \begin{tabular}{|c|}
-102.92 \\
\end{tabular} \\
\hline
\end{tabular}

TABLE 5. Results obtained for saturation step change and comparative analysis of Corey model

\begin{tabular}{|c|c|c|c|c|c|c|c|c|}
\hline & \multicolumn{5}{|c|}{ Corey } & \multicolumn{3}{c|}{ Deviation (\%) } \\
\hline & & & & & & \multicolumn{2}{c|}{ Well Sorted vs. Corey } \\
\hline $\mathbf{S}_{\mathrm{g}}$ & $\mathbf{K}_{\mathrm{ro}}$ & $\mathbf{K}_{\mathrm{rg}}$ & $\mathbf{Q}_{\mathbf{o}}$ & $\mathbf{Q}_{\mathbf{g}}$ & $\mathbf{f}_{\mathbf{g}}$ & $\mathbf{Q}_{\mathbf{o}}$ & $\mathbf{Q}_{\mathbf{g}}$ & $\mathbf{f}_{\mathbf{g}}$ \\
\hline & & & & & & & & \\
\hline 0.475 & 0.1855 & 0.0673 & 460.82 & 3.91 & 0.94 & 34.38 & -65.62 & -9.21 \\
\hline 0.45 & 0.2234 & 0.0515 & 555.06 & 2.99 & 0.91 & 31.25 & -68.75 & -13.37 \\
\hline 0.425 & 0.2669 & 0.0382 & 663.07 & 2.22 & 0.86 & 28.13 & -71.87 & -19.48 \\
\hline 0.4 & 0.3164 & 0.0273 & 786.13 & 1.59 & 0.79 & 25.00 & -75.00 & -28.35 \\
\hline 0.375 & 0.3725 & 0.0186 & 925.57 & 1.08 & 0.68 & 21.88 & -78.12 & -40.70 \\
\hline 0.35 & 0.4358 & 0.0119 & 1082.79 & 0.69 & 0.54 & 18.75 & -81.25 & -56.59 \\
\hline 0.325 & 0.5068 & 0.0070 & 1259.23 & 0.41 & 0.37 & 15.63 & -84.38 & -74.32 \\
\hline 0.3 & 0.5862 & 0.0037 & 1456.41 & 0.21 & 0.21 & 12.50 & -87.50 & -90.15 \\
\hline 0.275 & 0.6745 & 0.0016 & 1675.88 & 0.09 & 0.09 & 9.37 & -90.62 & -100.33 \\
\hline 0.25 & 0.7725 & 0.0005 & 1919.27 & 0.03 & 0.03 & 6.25 & -93.75 & -103.94 \\
\hline 0.225 & 0.8807 & 0.0001 & 2188.25 & 0.00 & 0.00 & 3.13 & -96.87 & -102.92 \\
\hline
\end{tabular}




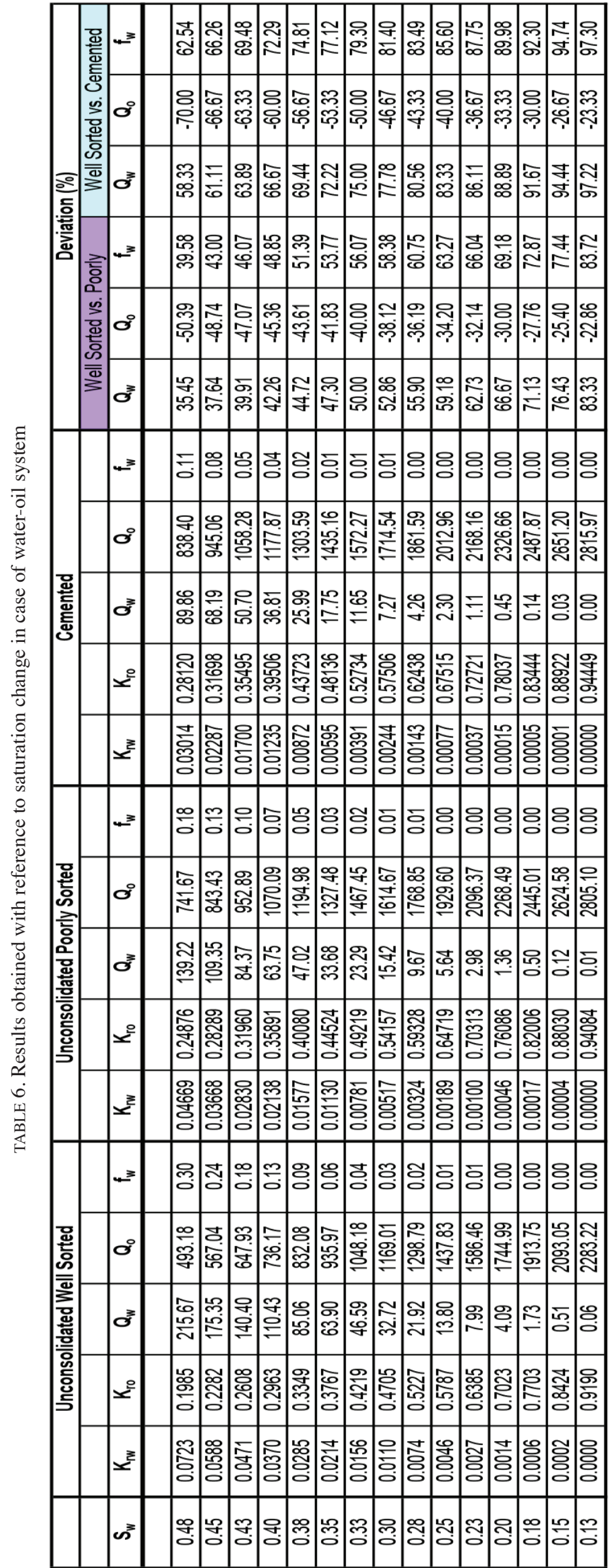




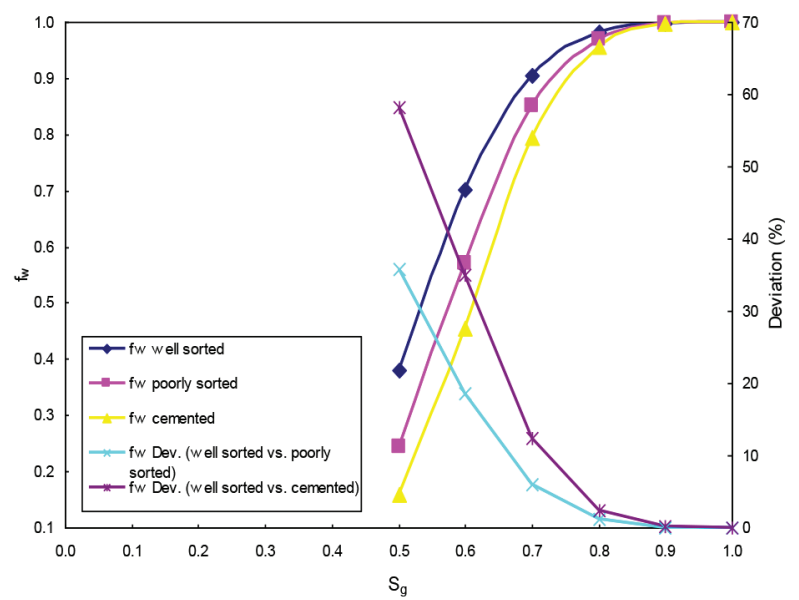

FIGURE 10. Water-cut and percentage error profile for water displacing oil system

\section{CONCLUSION AND RECOMMENDATIONS}

Variations in minimum saturation of the displaced phase affect the relative permeability data generated by using different models for gas- and water-oil displacement systems. Wylie and Gardner model for cemented formations undergoing gas-oil displacement (drainage) process gives results similar to Corey model. Moreover, in general, the behavior of models proposed by Wyllie and Gardner becomes vice versa based on fluid system (gas and oil-water) for the same formation type.

In order to analyze the effect of above discussed relative permeability models on reservoir performance, production rates and displacing fluid (gas and water) cuts have been calculated, which shows that the slight change in relative permeability have significant impact on reservoir performance calculations. This study shows that the deviation in generated production profiles in either displacement system for any particular fluid generally increases with the decrease in its saturation. This can be particularly observed specially in case of gas, which being lighter and having high mobility is least effected by degree of sorting and cementing and the difference in production profile and gas-cut becomes evident at lower gas saturations. Therefore, fluid saturation/end point saturation in a reservoir also affects the reservoir performance apart from pore size distribution (sorting) and degree of cementing, which was earlier a more commonly known and discussed fact in reservoir performance calculations. Therefore, the fluid saturation variations and model selection for reservoir studies should be taken into thorough consideration and need to be critically handled, for better reservoir exploitation and development.

\section{REFERENCES}

Ahmed, A., Al-Dulaimi, A., Hashim, S. \& Khan, M.I. 2011. Corrosion protection of carbon steel using polyaniline composite with inorganic pigments. Sains Malaysiana 40: 757-763.
Ahmed, T. 2000. Reservoir Engineering Hand Book. Burlington, MA: Gulf Pub. Co.

Craig, F.F. 1971. The Reservoir Engineering Aspects of Waterflooding. Monograph Series, SPE, Richardson.

Brooks, R.H. \& Corey, A.T. 1966. Properties of porous media affecting fluid flow. J. Irrig. Drain. Div. 92: 61-88.

Corey, A.T. 1954. The interrelation between gas and oil relative permeabilities. Producers Monthly 19: 38-41.

Economides, M.J., Hill, A.D. \& Ehlig-Economides, C. 1994. Petroleum Production Systems. Englewood Cliffs, NJ: Prentice Hall.

Serbini, F., Wee, L.K. \& Wong, L.H. 2009. Integrated field development - Improved field planning and operation optimization. International Petroleum Technology Conference, Doha, Qatar.

Gatlin, C. 1960. Petroleum Engineering - Drilling and Well Completion. New Jersey: Prentice-Hall Inc.

Naar, J. \& Henderson, J.H. 1961. An imbibition model - Its application to flow behavior and the prediction of oil recovery. Trans. AIME 1: 61-70.

Honarpour, M.M., Koederitz, L.F. \& Harvey, A.H. 1986. Relative Permeability of Petroleum Reservoirs. Boca Raton, FL: CRC Press, Inc.

Li, K. 2010. Correlation between resistivity index, capillary pressure and relative permeability. Proceedings Thirty-Fifth Workshop on Geothermal Reservoir Engineering.

Pirson, S.J. 1958. Oil Reservoir Engineering. New York: McGraw-Hill Book Co. Inc.

Ridha, B.C.G. 2003. Integrated reservoir simulation studies to optimize recovery from a carbonate reservoir. In SPE Asia Pacific Oil and Gas Conference and Exhibition. Society of Petroleum Engineers: Jakarta, Indonesia.

Wyllie, M.R.J. \& Gardner, G.H.F. 1958. The generalized KozenyCarmen equation - Its application to problems of multi-phase flow in porous media. World Oil 2: 121-146.

Zahoor, M.K. \& Derahman, M.N. 2013 New approach for improved history matching while incorporating wettability variations in a sandstone reservoir - Field implementation. Journal of Petroleum Science and Engineering 104: 27-37.

Zahoor, M.K., Derahman, M.N. \& Yunan, M.H. 2011. WAG process design - An updated review. Brazilian Journal of Petroleum and Gas 5(2): 109-121. 
Zahoor, M.K. 2011. In-house developed Kr estimator: Implemented to analyze the sensitivity of relative permeability data to variations in wetting phase saturation. Energy, Exploration \& Exploitation 29: 817-826.

Department of Petroleum and Gas Engineering University of Engineering and Technology, Lahore Pakistan
*Corresponding author; email: mkzahoor@yahoo.com

Received: 30 November 2013

Accepted: 24 August 2015 